\title{
До питання про побудову соціально орієнтованої ринкової економіки: соціологічний вимір
}

\section{Ніколенко В.В., Дніпровський національний університет імені Олеся Гончара}

У статті досліджено теоретичні основи побудови соціально орієнтованої ринкової економіки як господарської основи для формування держави загального добробуту. Зосереджено увагу на наукових ідеях і реформаторських зусиллях класиків цього наукового підходу: А. Сміта, Л. Ергарда, Н. Еліаса, О. Бісмарка, Г. Беверіджа, Є. Головахи. 3 огляду на їх праці соціально орієнтовану ринкову економіку слід розуміти як сукупність конкретних складників: 1) збільшення обсягів виробництва й ефективне подолання бідності; 2) увага до потреб споживача; 3) зменшення соціально-економічної дистанції між багатими та бідними; 4) становлення середнього класу приватних власників; 5) прагнення до конкуренції й соціального прогресу; 6) формування досяжницької мотивації й розширення можливостей для самореалізації людини; 7) підтримка громадянської та підприємницької ініціативи; 8) реалізація у повсякденному житті ідей ефективної правової держави, а також постійний пошук на цьому тлі бажаного компромісу між економічною ефективністю і соціальною справедливістю. Зроблено висновок, що формування соціально орієнтованого ринкового господарства найефективніше відбуватиметься за умови дієвості відповідного соціально-економічного механізму, перевіреного часом і практикою. Він передбачає: по-перше, релевантність (дихотомію) економічного і соціального; по-друге, поширення публічним простором європейських емансипативних і гуманістичних цінностей; по-третє, формування інтернального локусу психологічного самоконтролю особистості; по-четверте, перманентну увагу під час модернізації країни до соціально-психологічної реакції населення і стану громадської думки.

Ключові слова: соціально орієнтована ринкова економіка; держава загального добробуту; релевантність (дихотомія) економічного і соціального; європейські емансипативні та гуманістичні цінності; інтернальний локус психологічного контролю; досяжницька мотивація; соціальна політика

\section{On the question of building a socially oriented market economy: a sociological dimension}

\section{Nikolenko V. V., The Oles Honchar Dnipro National University}

The article investigates the theoretical foundations of building a socially oriented market economy as an initial stage for the formation of the state of welfare. It will not be an exaggeration to say that in today's society the demand for information on the search and comprehension of the primary sources of this paradigm, awareness and reflection on its classical theoretical foundations is growing. Therefore, in our opinion, it is advisable to revise the general panorama of the main ideas, generalizations of the classics of the genre, in order to understand the essence of this socio-economic system, to distinguish its relevant empirical indicators and outline the perspective trajectories of further development. The attention is focused on the scientific ideas and reform efforts of A. Smith, L. Ergard, N. Elias, O. Bismarck, G. Beveridge, E. Golovakha. In view of their scientific approaches, a socially oriented market economy should be understood as, on the one hand, a set of ideas about: 1) increasing production and effective poverty reduction; 2) paying attention to the needs of the consumer; 3) reducing the socio-economic distance between the rich and the poor; 4) becoming a middle class private owners, 5) desire for competition and social progress; 6 ) the formation of achievable motivation and the expansion of opportunities for self-realization of man; 7) support for civil and entrepreneurial initiative; 8) implementation of the ideas of an effective state of law in the everyday life, and on the other - a constant search on the background of the desirable compromise between economic efficiency and social justice. At the same time, the issue of choosing an effective paradigm of social policy deserves special attention in the processes of building a socially oriented market economy and «welfare state». In the modern world try to abandon the paternalistic and move on to maintaining an activist paradigm of social policy, which would create such a life motivation that allows as many of the population as possible to realize themselves in various dimensions of social life. It is concluded that the formation of a socially oriented market economy will most effectively take place taking into account the effectiveness of the socio-economic mechanism, which was tested by time and practice, and envisages: firstly, the relevance (dichotomy) of economic and social; second, the dissemination of the public space of European emancipation and humanistic values; thirdly, the formation of an internal locus of psychological self-control of the individual; fourthly, permanent attention to the socio-psychological reaction of the population and the state of public opinion during the modernization of the country.

Keywords: socially oriented market economy; state of welfare; relevance (dichotomy) of economic and social; European emancipatory and humanistic values; internal type of personality; achievement motivation; social policy 


\title{
K вопросу о построении социально ориентированной рыночной экономики: социологическое измерение
}

\author{
Николенко В. В., Днепровский национальный университет имени Олеся Гончара
}

В статье раскрыты теоретические основы построения социально ориентированной рыночной экономики как хозяйственной основы для формирования государства всеобщего благоденствия. Сфокусировано внимание на научных идеях и реформаторских усилиях классиков этого научного подхода: А. Смита, Л. Эргарда, Н. Элиаса, О. Бисмарка, Г. Бевериджа, Е. Головахи. В соответствии с их работами социально ориентированную рыночную экономику следует понимать как совокупность конкретных составляющих: 1) увеличение объемов производства и эффективное нивелирование бедности; 2) внимание к потребностям потребителей; 3) уменьшение социально-экономической дистанции между богатыми и бедными; 4) формирование среднего класса частных собственников; 5) стремление к конкуренции и социальному прогрессу; 6) формирование достижительской мотивации и расширение возможностей для самореализации человека; 7) поддержка гражданской и предпринимательской инициативы; 8) реализация в повседневной жизни идей эффективного правового государства, а также постоянный поиск на этом фоне желаемого компромисса между экономической эффективностью и социальной справедливостью. Сделан вывод, что формирование социально ориентированной рыночной экономики эффективнее всего будет происходить при условии действенности важного социально-экономического механизма, проверенного временем и практикой. Он предполагает: во-первых, релевантность (дихотомию) экономического и социального; во-вторых, расширение в публичном пространстве европейских эмансипативных и гуманистических ценностей; в-третьих, формирование интернального локуса психологического самоконтроля личности; в-четвертых, перманентное внимание в процессах модернизации страны к социально-психологической реакции населения и состоянию общественного мнения.

Ключевые слова: социально ориентированная рыночная экономика; государство всеобщего благоденствия; релевантность (дихотомия) экономического и социального; европейские эмансипативные и гуманистические ценности; интернальный локус психологического самоконтроля; достижительская мотивация; социальная политика

\section{Постановка проблеми.}

$\mathrm{Y}$ сучасному турбулентному світі значну увагу політиків, широкої громадськості, учених привертають питання побудови успішної країни або суспільства, де переважають щасливі люди. Останнім часом у науковій і публіцистичній літературі, мас-медійному просторі все частіше можна побачити найрізноманітніші рейтинги, у яких, вдаючись до порівняльного аналізу, глибоко висвітлюють усі сфери життєдіяльності соціуму. Зрозуміло, що з-поміж найбільш промовистих і резонансних рейтингів представники соціально-гуманітарних наук мають зосереджувати увагу передусім на тих, де йдеться про конкурентоспроможність, емоційну й інвестиційну привабливість країни, відчуття соціального комфорту i щастя пересічної людини. На нашу думку, ці показники та їх динамічні особливості є одними із системоутворювальних щодо об'єктивного сприйняття реальної соціальної ситуації, з одного боку, й оцінки ефективності модернізації країни, наявних суспільних прагнень посісти престижне місце серед країн-лідерів глобального світу - 3 іншого.

3 огляду на це вважаємо, що фокус дослідницького інтересу слід концентрувати на досвіді демократичної модернізації й реформаторських практиках, насамперед, країн Західної Свропи і Північної
Америки. Цілком очевидно, що саме там можна спостерігати та виокремити бажані соціально-економічні зразки повноцінного життєзабезпечення масової людини. Такі практики і характерні соціальні стандарти зумовлюють зайняті ними провідні місця у світових табелях про ранги, наприклад, стосовно індексу розвитку людського потенціалу або найщасливіших країн світу. Тож абсолютно закономірно, що уряди країн-лідерів світового розвитку намагаються утримати пальму першості, зберегти позитивну динаміку в багатьох загальносвітових рейтингах завдяки реалізації превентивної політики, яка грунтується на основних принципах соціально орієнтованої ринкової економіки як господарської основи для побудови держави загального добробуту.

\section{Аналіз досліджень і публікацій.}

У науковому дискурсі проблематику побудови соціально орієнтованого ринкового господарства розробляли представники потужного корпусу дослідників. Серед західних учених слід відзначити концепції й напрацювання А. Сміта, Л. Ергарда, Г. Беверіджа, Й. Шумпетера, Н. Еліаса, Г. Еспінг-Андерсена, А. Мюллер-Армак, Ф. Хайєка, М. Мюрдаля, Д. Гелбрейта та ін. Серед вітчизняного наукового доробку варто виділити праці В. Ворони, Є. Головахи, В. Бакірова, М. Шульги, Е. Лібанової, Т. Петрушиної, О. Балакірєвої, 
В. Пилипенка, С. Суїменка, Ю. Пачковського, В. Резніка, С. Сірого. Водночас не буде перебільшенням сказати, що у сучасному соціумі зростає затребуваність інформації щодо пошуку й осмислення першоджерел цієї парадигми, усвідомлення та рефлексії стосовно іiі класичних теоретичних основ, фіксації основних метричних параметрів цього феномена. Тож, на нашу думку, доцільно здійснити теоретичну ревізію основних ідей, узагальнень класиків жанру, щоб зрозуміти сутність цієї соціально-економічної системи, виокремити її релевантні емпіричні індикатори й окреслити перспективні траєкторії подальшого розвитку.

Отже, метою цієї статті $\epsilon$ спроба концептуалізувати важливі ідеї соціально орієнтованої ринкової економіки як господарської основи для формування держави загального добробуту, головне призначення якої - це прагнення до постійного підвищення рівня, якості життя і соціального самопочуття пересічної людини.

\section{Виклад основного матеріалу.}

Очевидно, цікаві ідеї досягнення соціально-економічного успіху держави існували ще в античні часи. Так, слід згадати працю Аристотеля «Політика», у якій він відстоював інтереси середньої верстви і розмірковував над долею багатих і бідних груп суспільства. У цьому контексті доречно згадати релевантні концепції відомих громадсько-політичних діячів, учених минулого, a саме: Ж. Ж. Руссо, Т. Джефферсона, Г. Гегеля, А. Токвіля, В. Вільсона, О. Бісмарка.

По суті, дихотомію соціально орієнтованої ринкової економіки та держави загального добробуту не слід сприймати окремо від процесів розвитку та реалізації основних норм, практик і принципів громадянської самоорганізації й ініціативи, демократичних інститутів, формування капіталізму «з людським обличчям», ефективного функціонування правової держави. Так, ініціатори впровадження у повсякдення громадянських прав (перше покоління), політичних (друге покоління) та соціально-економічних (трете покоління) значною мірою посприяли формування фундаменту цього феномену. Наприклад, ще I. Кант вважав правову державу невід'ємним елементом демократії, без якої не існує вільної економіки. Зрозуміло, що створення такої держави - це довготривалий процес. Загалом правовою називають державу, яка відповідає, як мінімум, трьом критеріям: а) панування закону в усіх сферах суспільного життя; б) виконання представниками державних структур законів на рівні з усіма іншими, в) судовий захист прав громадян і взаємна відповідальність держави й особистості. Правову державу часто небезпідставно асоціюють із громадянським суспільством - мережею недержавних, некомерційних організацій, які виконують важливі, соціально схвалювані суспільні функції й подекуди виступають посередником у діалогових формах взаємодії держави та пересічної людини. Важливо зазначити, що у країнах, де державу контролює громадянське суспільство розвиток капіталізму відбувається найефективніше (Англія, США, Франція, Німеччина, Австрія тощо). Таким є загальне бачення бажаних політичних і соціально-економічних процесів на макрорівні. Однак, доказовою може бути лише розлога аргументація, тому спробуємо конкретизувати наші пошуки й узагальнення методологічного фарватеру і теоретичних першоджерел відносно побудови суспільства 3 високими соціально-економічними стандартами життя.

Стосовно методологічних орієнтирів варто зауважити на перманентному використанні державами західної цивілізації наукових моніторингових даних із метою впровадити в життя ефективні економічні та соціальні програми. Саме емпіричні показники рівня і якості життя середньої особи, динаміки ііі острахів/фобій, емоційного стану, соціально-психологічного й інших вимірів здоров'я, упевненості у майбутньому, наявності широких можливостей для самореалізації, рівня платоспроможності домогосподарств мають бути лакмусовим папірцем оцінки результативності реформ і будь-яких інших нововведень. Це вимагає від можновладців усіх рівнів постійної уваги до широкої бази систематичних наукових даних, щорічних соціологічних звітів, статистичних оглядів, які промовисто говорять про стан громадської думки, масової свідомості, соціальні настрої, очікування населення тощо. Так, урядовці профільних міністерств успішних країн глобального світу саме 3 огляду на такі моніторингові дані постійно формулюють і пропонують на розсуд громадськості змістовні відповіді на конкретні запитання щодо збереження позитивної динаміки якості життя населення, покращення його соціального самопочуття, суспільного комфорту масової людини тощо.

Учені невипадково наголошують, що громадська думка, сформована по закінченню епохи середньовіччя у результаті розширення публічної сфери ${ }^{1}$, стала виконувати функції однієї з повноцінних гілок влади. Досвід національного будівництва західних країн переконливо доводить, що без врахування цієї інформації годі й сподіватись на успішну трансформа-

\footnotetext{
${ }^{1}$ Вважають, що громадська думка існувала в усі історичні епохи. Водночас В. Бурлачук небезпідставно виокремлює підхід, відповідно до якого вона остаточно формується з появою буржуазного суспільства, просвітницького розуму і розширенням публічної сфери [4].
} 
цію елітарно-ієрархічної моделі соціальної структури в егалітарно-демократичну, на побудову ефективної, консолідованої демократії, соціально оріснтованої ринкової економіки і держави загального добробуту. Примітно, що у минулому на значущості громадської думки для соціально-політичного й економічного життя суспільства неодноразово зауважували багато видатних вчених. Наприклад, іспанський філософ Х. Ортега-і-Гассет акцентував, що закон громадської думки є свого роду законом всесвітньої гравітації у сфері політичної історії, без якого історія не була б наукою. Дослідник наголошує: одне із завдань історії - довести, що сила громадської думки - не утопічна мрія, а справжня реальність, яка постійно діє в житті суспільства [1, с. 127]. Подібні думки висловлювали шотландський філософ і економіст Д. Г’юм [2], а також філософ і соціолог С. Л. Франк [3, с. 73]. Так, останній постійно зауважував, що громадська думка як сукупність і рівнодійна панівних вірувань, очікувань, прагнень і настроїв $є$ універсальною основою будь-якого політичного і соціального порядку, перманентним двигуном національного прогресу й доленосних перетворень. Тож, для суб'єктів політичних і ринкових трансформацій емпіричні дані реального стану суспільства, його соціально-економічного клімату можуть стати запорукою впевненості канатохідця у процесах обговорення і прийняття важливих управлінських рішень. Адже без урахування соціально-психологічної реакції соціуму на процеси модернізації суспільства будь-які нововведення будуть дисфункціональними, відповідно, не принесуть очікуваного результату.

Стосовно теоретичних першоджерел побудови соціально орієнтованого ринкового господарства вважаємо за необхідне звернути увагу, насамперед, на думки класиків жанру: Л. Ергарда, А. Сміта, О. фон Бісмарка, Г. Беверіджа, Є. Головахи. Доцільно особливо закцентувати на реформаторському досвіді одного із видатних науковців, якого по праву вважають теоретиком і батьком-засновником економічного дива повоєнної Німеччини - Л. Ергарда. Німецьке диво у подальшому стало моделлю для багатьох вдалих прикладів модернізації сьогодні вже успішних країн світу - Іспанії, Тайваню, Південної Кореї тощо. Не зважаючи на непросту долю, Л. Ергард як практик політекономії надовго залишиться у пам'яті вдячних нащадків і прийдешніх поколінь державником, який свого часу допоміг Німеччині ефективно подолати глибоку соціально-економічну кризу завдяки будівництву вільного і відповідального господарства. Нагадаємо, що він працював міністром економіки в уряді бунде- сканцлера К. Аденауера після Другої світової війни. У своїй праці «Добробут для всіх» ${ }^{2}$ Л. Ергард особливо зауважував, що він був міністром господарства всієї Німеччини, а не мембраною або рупором інтересів окремих фінансово-промислових груп. Водночас адресатом його економічних реформ по праву можна вважати насамперед пересічного споживача, а їх кінцевою метою - прагнення до постійного підвищення стандартів життя населення. За Л. Ергардом основні ідеї соціально орієнтованої ринкової економіки в узагальненому вигляді можна сформулювати так: 1) невтручання держави в господарське життя; 2) дотримання особистих прав і свобод, зокрема права кожного громадянина змагатись 3 іншими щодо власних досягнень; 3) економічна конкуренція; 4) свобода вибору споживача; 5) виробництво, що покриває всі внутрішні потреби; 6) приблизно десята частина зайнятого населення має працювати у сфері будівництва; 7) конкурентність промислової продукції на світовому ринку та позитивне торговельне сальдо, 8) усвідомлення громадянами сенсу необхідності виробничої праці; 9) постійне зростання економічного добробуту суспільства, тобто збільшення ВВП на душу населення; 10) соціальна справедливість і прогрес; 11) піклування про традиції приватної власності й середній клас [5]. Сукупність таких ідей-маркерів $\epsilon$ одним із можливих барометрів, який показує наближення чи віддалення від природи, сутності соціально орієнтованого господарства. Німецький учений, спираючись на основні критерії істини - час і практику, переконливо довів, що реалізація цих ідей приведе до зменшення тіньової економіки, підвищення господарської активності, поширення соціально бажаних зразків економічної діяльності людини, зокрема поваги до виробничої праці. Нагадаємо, що в англомовній науковій традиції певні аспекти подібної проблематики відомі під назвою «welfare state», або держави загального добробуту, зокрема в дослідженнях Г. Еспінг-Андерсена.

Практик політекономії Л. Ерхард був послідовним прихильником ринкової демократії. Головною метою його діяльності було створення суспільства, у якому немає знедолених. Таке бачення проблемної ситуації суміжне 3 поглядами багатьох інших відомих учених. Так, на думку Е. Гідденса, ринок - це найраціональніший економічний регулятор розподілу ресурсів, який до того ж оптимальний $з$ позицій моралі. Загалом підприємництво та ринок - це два іманентні боки однієї медалі, названої капіталізмом. 3 огляду на це можна говорити про основи підприємницько-капіталістичної

\footnotetext{
2 Причому добробут для всіх (у вигляді підвищення заробітку, свободи споживання, зниження цін) - це термінальна цінність, а конкуренція - інструментальна [5, с. 15].
} 
системи та іiї новаторський, вільний дух. Зокрема, підприємницькому духові непритаманні загальна зрівнялівка, звалювання відповідальності на інших, прагнення до незмінності свого положення. Подібні думки висловлював лауреат Нобелівської премії Ф. фон Хайєк. Розмірковуючи стосовно специфіки двох соціально-економічних систем (редистрибутивної й ринкової), він зауважував, що для планово-адміністративної або редистрибутивної економіки характерна наявність декількох людей, які послуговуючись нікому не відомими принципами, вирішують, що, кому й у якій мірі доцільно примусово розподілити. Натомість у ринковому господарстві успіх і визнання людини залежить «від іiї власних здібностей, заповзятливості та певною мірою від непередбачуваних обставин» (цит. за: [5, с. VI]). Те саме переконливо говорив і доводив власною практичною діяльністю Л. Ерхард у діалозі з прихильниками редистрибутивної економіки. Симптоматично, що на тлі таких обставин лише від людини й нікого іншого (маємо на увазі чиновників, різноманітних ієрархів, керівництва промислових підприємств тощо), залежить іiі доля, визнання, успіх або навпаки - невдачі. Можна стверджувати, що це ідеальне суспільне тло для популяризації та поширення особистості інтернального типу - соціально активної, незалежної, ініціативної, конкурентоспроможної, заповзятливої, енергійної, відповідальної, з сильною мотивацією досягнення й самоствердження. Важливо зазначити, що подібні особистісні якості $\epsilon$ необхідними для розвитку будь-якої нації та навіть доленосними.

Загальний знаменник такого типу організації соціально-економічної системи полягає не лише в раціоналізації професійної діяльності, збільшенні ВВП на душу населення, але й у налагодженні ефективного соціального забезпечення, як результат - створення більш сприятливих можливостей для повноцінної самореалізації людини. Так, Л. Ерхард наголошував, щоб соціальна спрямованість ринкового господарства не залишалася пустим звуком, слід не удосконалювати розподіл матеріальних благ, а піднімати виробництво. Жодна державна влада, жодні профспілкові союзи не здатні сприяти соціальному прогресу, якщо економіка перебуває на низькому рівні $[5$, с. 81]. Іншими словами, соціально орієнтована ринкова економіка як господарська основа для держави загального добробуту - це постійний пошук компромісу між економічною ефективністю і підтримкою соціальної сфери, господарським інтересом і соціальною справедливістю, прагненням до самозабезпечення і багатства всього суспільства. Причому знаходжен- ня такого компромісу грунтується на перманентному зростанні виробництва, сприяючи розвитку соціальної сфери і жодним чином не порушуючи високих стандартів господарської культури, досяжницької мотивації.

У межах цієї дихотомії варто окремо зупинитися на важливих аспектах взаємодії, точніше, релевантності соціального й економічного. Очевидно, що одним з основних завдань для суб'єктів побудови «welfare state» стає унеможливлення створення дуалістичного суспільства, де багатство зосереджене в руках незначного прошарку економічно неактивного населення, натомість представники висококваліфікованих спеціальностей залишаються на узбіччі фінансового благополуччя. 3 огляду на це на особливу увагу заслуговує питання щодо створення передумов для ефективного вирішення проблеми матеріального забезпечення, підвищення рівня купівельної спроможності різноманітних соціально-професійних груп, передусім затребуваних спеціальностей, у сучасному турбулентному світі - медиків, програмістів, військових, інженерно-технічних і соціальних працівників, викладачів, науковців тощо. Наприклад, Л. Ергард підкреслював, що його реформи мають на меті не лише задоволення життєво необхідних матеріальних інтересів населення, але й поширення у домашньому господарстві товарів довготривалого користування (холодильників, пральних машин, пилососів тощо) [5, с. 77]. Більше того, ці перетворення привели до трансформації продуктів преміум-класу в категорію товарів широкого вжитку, що $є$ конкретною, фіксованою ознакою успішних господарських реформ.

Такі акценти стають гідною мотивацією для професійної соціалізації молоді, водночас створюючи важливі підстави для збільшення відрахувань до пенсійного фонду. Очевидно, варто робити рішучі реформаторські кроки задля запобігання консервації бідності та зведення нанівець ії небезпечної субкультури. Якщо ми прагнемо побудувати демократичне суспільство, слід розуміти, що без повноцінного задоволення вітальних, матеріальних потреб важко сподіватись, 3 одного боку, на створення міцного середнього класу, дієву громадянську самоорганізацію й ініціативу, а 3 іншого - на стрімке поширення публічним простором європейських емансипативних і гуманістичних цінностей. Ідеться про такі бажані цивілізаційні орієнтири, як взаємопідтримка, солідарність, довіра, самореалізація, свобода, толерантність, підприємництво, мотивація досягнення і самоствердження, егалітаризм, терпимість, емпатія, функціонування комунікативного розуму (за Ю. Габермасом). Так, сам Л. Ерхард зазначав, що постійний економічний прогрес 
як похідна його реформаторської політики став можливим лише завдяки високому рівню довіри до уряду з боку суспільства [5, с. XVI]. Важливу роль зіграло й несприйняття непотизму, абсолютного патерналізму, планово-адміністративної економіки, соціального утриманства тощо.

Без означених вище соціальних практик та їх атрибутивних ціннісних елементів демократична система майже не працює, стає дисфункціональною. Доречно згадати доволі цікаву крос-культурну закономірність: заможні люди за власною соціальною природою ліберальні, натомість бідні, як правило, нетерпимі. Тож суспільство без середнього класу, ефективних громадянських ініціатив навряд зможе досягти успіху в процесах прискореної демократичної модернізації країни, адже іії головними суб'єктами є дрібна і середня буржуазія, студентство, молодь, інтелігенція, економічно активне населення.

Більше того, через невирішеність важливих, навіть доленосних питань матеріального благополуччя у такому суспільстві матимуть місце небезпечні деградаційні процеси. Так, Є. І. Головаха неодноразово зауважував, що в поляризованих суспільствах 3 ознаками глибокої соціально-економічної диференціації, де існує величезна соціальна дистанція між бідними і багатими, загальна кількість людей, незадоволених різними аспектами власного життя, на порядок вище, ніж у суспільствах середнього класу. Тож невипадково за даними всесвітніх рейтингів найщасливіші люди проживають у Скандинавії, де пропорція між десятьма відсотками найбільш і найменш забезпечених верств населення перебуває приблизно на позначці один до семи (1/7) або один до восьми (1/8), але не більше. Водночас на Всесвітньому економічному форумі (2017) фахівці відзначили, що Фінляндія і Норвегія - країни з найнижчим рівнем організованої злочинності. На тлі подібних практик запобігання корупції відбувається повноцінний розвиток малого i середнього бізнесу, а його представники повною мірою сплачують податки до місцевих бюджетів. Це, у свою чергу, приводить до розширення можливостей вирішення важливих соціальних питань. Отже, Норвегія в рейтингу найщасливіших країн 2017-го року (World Happiness Report) ${ }^{3}$ посідає перше місце, за нею розташовані - Данія, Ісландія, Фінляндія, Нідерланди, Канада, Нова Зеландія, Австралія і Швеція. Можна сміливо стверджувати, що для всіх цих країн характерні суспільства середнього класу. Прагнення наблизитись до провідних позицій у цьому списку у котре актуалізує питання про зосередження реформаторських зусиль, насамперед, на проблемах ефективного подолання бідності й формування міцного середнього класу.

3 огляду на це, доцільно звернутись до порад одного з класиків політекономії А. Сміта й евристичного потенціалу його універсальних законів ринкового господарства. Свого часу шотландський учений і його послідовники ототожнювали економіку з так званою «невидимою рукою» $\mathrm{i}$ доводили ефективність підходу, який на сьогодні відомий під назвою «laissez faire», що у перекладі 3 французької мови означає «дозвольте робити». Утілення цього принципу відкрило дорогу до реалізації досі небачених економічних сил. Його обгрунтовували, зважаючи на те, що державні структури не повинні заважати легальній виробничій діяльності тих соціальних груп, які прагнуть реалізувати себе за допомогою власної ділової ініціативи і виконувати соціально-економічну роль важливого рушія розвитку господарської сфери - буржуа, підприємців, капіталістів, фермерів. А. Сміт зазначав, що на цій основі попит породжує пропозицію, а за умови вільного пересування економічно активного населення і капіталу економіка стає самодостатньою, саморегульованою системою, у результаті чого - збагачується все суспільство. Проте не варто забувати, що закони ліберальної економіки А. Сміта і Л. Ергарда ефективно працюватимуть лише за наявності важливого соціального складника, який, окрім уже зазначеного, передбачає: 1) наявність значущого ресурсу довіри для зменшення трансакційних витрат; 2) ефективну боротьбу з корупцією; 3) скорочення соціальної та економічної дистанції між найбільш і найменш забезпеченими верствами населення; 4) дотримування традицій соціально відповідального бізнесу; 5) культурно прийнятну поведінку представників елітарних прошарків. Тож ринкова економіка ефективно працюватиме лише за умови наявності відповідного соціокультурного тла.

На нашу думку, на особливу увагу у процесах побудови «welfare state» заслуговують питання вибору дієвої парадигми соціальної політики. У всьому цивілізованому світі прагнуть відмовитися від патерналістської парадигми соціальної політики на користь активістської, за якою можна сформувати таку життєву мотивацію, що дозволить якомога більшій частині населення реалізувати себе в різноманітних вимірах суспільного життя. Про певні ознаки такого досяжницького духу свого часу зауважував колишній прем'єр-міністр Великобританії У. Черчилль.

\footnotetext{
${ }^{3}$ Методологія проведення дослідження передбачала врахування: 1) ВВП на душу населення, 2) очікуваної тривалості життя, 3) соціальної підтримки з боку родичів або друзів, 4) свободи вибору в житті, 5) рівня благодійності, 6) сприйняття корупції.
} 
Зокрема, він неодноразово зазначав, що ми повинні остерігатися створення такого суспільства, де люди, за винятком політичних діячів і посадових осіб, нічого не варті; суспільства, де ініціативу не винагороджують, а ощадливість не приносить благ. Безсумнівно, для абсолютної більшості самореалізація може мати місце лише в демократичній системі, на відміну від тоталітарної з іiі перманентними тенденціями до формування екстернальної життєвої позиції, тобто домінування у масовій свідомості експектацій на кшталт «про мене піклуватимуться інші». Цей соціальний феномен має ще одну промовисту назву - соціальне утриманство. До речі, серед населення Заходу переважає інтернальний локус особистісного самоконтролю. Інтернали пов'язують відповідальність за власну долю лише з особистими зусиллями, наполегливою працею. На цьому тлі можна простежити два стрижневі принципи впливу на поведінку людини: зовнішній примус і внутрішню мотивацію. Н. Еліас зауважував, що процес цивілізації є трансформацією домінантної структури зовнішнього примусу з боку держави у напрямку до формування дієвого особистісного самоконтролю окремої людини, зважаючи на іiї власну мотивацію, індивідуальні переконання тощо [6]. 3 огляду на це активістський тип соціальної політики передбачає формування у масовій свідомості рельєфно вираженої досяжницької мотивації або, як мінімум, не заважає цьому. Така парадигма змінює соціальну семантику людини від iii сприйняття як об'єкта впливу на визнання за нею диспозицій суб'єкта, здатного бути дієвим творцем власної біографіі. На цьому тлі активістський тип соціальної політики є органічним елементом процесу цивілізації, за Н. Еліасом. Утім це не означає, що всі нужденні соціальні групи, які з огляду на різні причини неспроможні у повному обсязі самостійно себе забезпечити, згідно з соціально-дарвіністськими поглядами залишаються сам на сам зі своїми проблемами. Для них існує виважена державна політика ефективного соціального забезпечення.

Деталізуючи цей аспект, слід виділити характерні підтипи такої соціальної політики і зауважити відповідні країни, яким вони притаманні. 1) континентальний підтип (Німеччина, Австрія, Бельгія, Нідерланди); 2) англосаксонський (США, Канада, Великобританія); 3) середземноморський (Греція, Іспанія, Італія); 4) скандинавський (Швеція, Фінляндія, Норвегія, Данія).

Концепція держави загального добробуту Г. Еспінг-Андерсена передбачає застосування дещо іншої типології, а саме виокремлення іiі ліберальної, соціально-демократичної та консервативної версій. Їх загальний сенс зводиться до постійного пошуку най- ефективнішого відсотку перерозподілу ВВП коштом бюджету країни, допомоги недержавних громадських та комерційних організацій 3 метою підтримати у тонусі соціальну сферу, створити комфортні умови проживання для якомога більшої частини населення і продукувати високі зразки господарської культури.

На цьому тлі в історії європейських країн виокремлюють як мінімум дві найбільш поширені й всеохоплюючі моделі соціальної політики: бісмарківську і беверіджську. Вони є двома полюсами в широкому континуумі, де постійно шукають бажаний компроміс між економічним і соціальним. Ці моделі є похідними наукової та суспільно-політичної діяльності двох видатних особистостей свого часу. О. фон Бісмарк - «залізний» канцлер Німеччини, активний прихильник інституту приватної власності, що виступав проти редистрибутивної парадигми організації господарського життя. Під час промов він неодноразово наголошував, якщо бажаєте будувати редистрибутивне господарство оберіть країну, яку вам не шкода. Примітним є те, що велика увага цього видатного державного діяча минулого була зосереджена на цінності освіти, конкурентних знань. Зокрема, він наголошував, що, з одного боку, навчатися необхідно так, неначе доведеться жити вічність, а 3 іншого - що людина має високо цінувати кожен день життя і не відкладати на завтра те, що можна зробити сьогодні. Крім того, маючи превентивний стиль мислення, німецький політик вважав, що будь-якій прогресивній країні необхідно будувати школи й університети, інакше завтра доведеться будувати в'язниці. Зважаючи на це, буде доречним навести приклади успішних країн сучасного світу, у яких збільшення інвестицій в освітню сферу приводить до підвищення рівня ВВП. Тож невипадково його ім'ям названо одну 3 найдієвіших моделей соціальної політики, що передбачає можливість фінансового забезпечення на соціально схвалюваному рівні будь-якої людини у разі втрати нею працездатності або виходу на пенсію. Цю допомогу здійснюють коштом виплат зі страхових фондів, у які людина сплачувала внески протягом економічно активного життя.

Г. Беверідж - колишній директор школи економічних і політичних наук у Лондоні. Фокус своєї дослідницької уваги зосереджував здебільшого на вивченні проблем вільної економіки, процесів зайнятості та безробіття. Суть беверіджської моделі соціальної політики полягає у прагненні до побудови солідарної системи соціального забезпечення, де передбачено загальнодоступну можливість отримувати систематичну допомогу з боку держави без урахування ступеня економічної активності в минулому. Незважаючи на незначні елементи начебто патерналізму, 
Г. Беверідж напевно залишиться у пам'яті нащадків послідовним прихильником вільного суспільства та, як результат, ринкової господарської культури. Водночас яку б модель із цього різноманітного списку підтипів активістської парадигми соціальної політики ми не обрали, для всіх дослідників, насамперед, актуальні питання збереження і підтримки культури досяжницької мотивації та самоствердження людини.

\section{Висновки.}

Підсумовуючи, необхідно наголосити, що ідеї ліберальної економіки, конкуренції, збільшення виробництва, високої досяжницької культури - надзвичайно важливі, але далеко не самодостатні елементи у складному соціально-економічному механізмі, який дозволяє успішним країнам ефективно вирішувати доленосні питання на шляху до власної модернізації. Подолання бідності, формування міцного середнього класу, розвиток громадянської та підприємницької ініціативи, реалізація ідей правової держави виступають, з одного боку, родючим тлом, а $з$ іншого - $є$ результатом дії такого механізму. Не претендуючи на охоплення всіх його елементів, адже економіці та господарському прогресу не властиві абсолютні шаблони, наголосимо, що йдеться, насамперед, про такі системоутворювальні складники: 1) релевантність (дихотомія) економічного і соціального; 2) домінування у публічному просторі емансипативних і гуманістичних цінностей; 3) поширення інтернального локусу особистісного самоконтролю; 4) перманентна увага до наукових досліджень стосовно соціально-психологічної реакції населення і стану громадської думки. Саме на такому суспільному тлі, з одного боку, буде розширено можливості для самореалізації людини та підтримки культури досяжницької мотивації, що працюватиме на користь всього суспільства, а 3 іншого - ефективно забезпечено на прийнятному рівні потреби найбілыш нужденних груп населення завдяки відповідному рівню розвитку соціальної сфери та інфраструктури. Саме в цьому, на нашу думку, полягає квінтесенція ідей побудови на сучасному етапі соціально орієнтованої ринкової економіки як господарської основи для суспільства загального добробуту.

\section{БІБІЛІОГРАФІЧНІ ПОСИЛАННЯ}

1. Ортега-и-Гассет Х. Восстание масс / Х. Ортега-и-Гассет // Вопросы философии. - 1989. - № 4. - С. 114-155.

2. Юм Д. Исследование о человеческом разумении / Д. Юм. - М.: Издательская группа «Прогресс». 1995. - 210 с.

3. Франк С. Л. Политика и идеи (О программе «Полярной Звезды») / С. Л. Франк // Сочинения. - М.: Правда, 1990. - С. 65-76.

4. Бурлачук В. Ф. Суспільна думка і просвітницький розум / В. Ф. Бурлачук // Методологія, теорія та практика соціологічного аналізу сучасного суспільства. Зб. наук. праць. - 2012. - Вип. 18. - С. 17-22.

5. Эрхард Л. Благосостояние для всех / Л. Эрхард. - М.: Начала-Пресс, 1991. - 224 с.

6. Еліас Н. Процес цивілізації: соціогенетичні і психогенетичні дослідження. Т. І-ІІ / Н. Еліас. - Київ: ВД «Альтернативи», 2003. - 700 с.

\section{REFERENCES}

1. Ortega-i-Gasset, H. (1989). Vosstanie mass [Rebellion of the masses]. Voprosy filosofii 4, 114-155 [in Russian].

2. Yum, D. (1995). Issledovanie o chelovecheskom razumenii [The study of human understanding]. Moscow: Izdatelskaya gruppa «Progress» [in Russian].

3. Frank, S.L. (1990). Politika i idei (O programme «Polyarnoy Zvezdy») [Politics and ideas (About the «Polar Star» program)]. Sochineniya. (pp. 65-76). Moscow: Pravda [in Russian].

4. Burlachuk, V.F. (2012). Suspilna dumka i prosvitnytskyi rozum [Public opinion and educational mind]. Metodolohiia, teoriia ta praktyka sotsiolohichnoho analizu suchasnoho suspilstva, 18, 17-22 [in Ukrainian].

5. Erhard, L. (1991). Blagosostoyanie dlya vseh [Welfare for all]. Moscow: Nachala-Press [in Russian].

6. Elias, N. (2003). Protses tsyvilizatsii: sotsiohenetychni i psykhohenetychni doslidzhennia [The process of civilization: sociogenetic and psychogenetic research]. Vol. I-II. Kiev: VD «Alternatyvy» [in Ukrainian].

\section{Ніколенко Вадим Вікторович}

Доктор соціологічних наук, професор кафедри соціології Дніпровський національний університет ім. О. Гончара 49010, Дніпро, пр. Гагаріна, 72

\section{Nikolenko Vadym}

Doctor of sociological sciences, prof. of the Department of Sociology The Oles Honchar Dnipro national university

72, Gagarin Av., Dnipro, 49010, Ukraine

\section{Email: vadnikolenko1983@gmail.com}

Цитування: Ніколенко В. В. До питання про побудову соціально орієнтованої ринкової економіки: соціологічний вимір / В. В. Ніколенко // Науково-теоретичний альманах «Грані». - 2018. - Т. 21. - № 5. - С. 20-27.

Citation: Nikolenko, V.V. (2018). Do pytannia pro pobudovu sotsialno oriientovanoi rynkovoi ekonomiky: sotsiolohichnyi vymir [On the question of building a socially oriented market economy: a sociological dimension]. Scientific and theoretical almanac "Grani», 21(5), 20-27. 